\title{
Comparative Study of Manakib Nurul Burhani Book with Jawahirul Ma'ani and The Teachings of Sufism in the Book Hagiography
}

\author{
Moh. Ashif Fuadi \\ Raden Mas Said State Islamic University of Surakarta \\ Jalan Pandawa Pucangan Kartasura \\ E-Mail: moh.ashiffuadi@iain-surakarta.ac.id
}

Abstract: Most of the people, especially nahdliyin residents, still follow the practice of manakib Sheikh Abdul Qadir al-Jailani. They do this to obtain the blessings of life. There are two most significant mainstream works in the reading of manakib, and the first is the book Nurul Burhani by K.H. Muslih Mranggen, and the second is the book of Jawahirul Ma'ani by K.H. Jauhari Umar Pasuruan. Each is read by many practitioners of manakib, which basically explains the biography of Abdul Qadir al-Jailani. This research is a comparative study of the historical two books by the method of library study. The results of this study are that books with each other have similarities and differences, even similarities in the content and editorial side. In a historical review, the authorship of the book influences by the experiences of different authors. Nurul Burhani's book consists of eight parts, while the book of Jawahirul Ma'ani has ten features. Each has a lot in common in the teachings of Sufism that Always act on the truth, a figure is always connected with God at the time of dhikr and live the laws of God and be founded the teaching of Sufism like mujahadah, riyadhah, wara', zuhud, khauf, qona'ah, sabar, syukur, muraqabah.

Keywords: Comparative-Content, Sufism, Nurul Burhani, Jawahirul Ma'ani. 


\section{A. InTRODUCTION}

The Sheikh Abdul Qadir al-Jailani manakib is still a tradition that many people favor, especially nahdliyin (residents of Nahdlatul Ulama) and pesantren (Islamic boarding schools). They practice manakiban as wirid carried out istikomah (sustainable) through wasilah (intermediary), the lovers of God, or auliya. They also believe that through the intermediary, the guardians can answer all the things or desires of worldly or ukhrowi (Fuadi \& Ibrahim, 2020: 2 ). Some places hold such activities known as dulqadiran, sewelasan, and mujahadahan.

The many activities of manakib indeed can't be separated from a Kiai or mursyid (spiritual of teacher) who provides encouragement and motivation to taqarrub (closer) to God, fostering a sense of mahabbah (love) Rasulullah, and know the guardians of God. In the scope of the world of order, a mursyid always to do tarbiyah (educate) his students to be inspired by the teachings of the founder of the order, such as the Qadiriyah order that adheres to the concept of Sufistic teachings Sheikh Abdul Qadir al-Jailani. In pesantren (Islamic boarding school), especially pesantren of the salaf, a Kiai will teach him to read portraits of salafush salih (pious predecessors) so that they want to follow the stages of education that he went through, starting from the process of cleaning birth and tazkiyyatu al-Nafs (inner purification). Similarly, in the scope of the community faced with various compound situations, it will affect each individual to get out of multiple problems towards a better position (Yahya, 2020: 17). By looking at the various phenomena above, it is not sur-

prising that many people firmly believe that reading manakib can overcome various problems of life faced. Man innately has a dhoif (weak) side before God, so that fuyūdhot al-Ilāhiyyah needs the blessings of the guardians mentioned in multiple books manakib (Zahro, 2020: 49).

Among the two mainstream manakib books most widely practiced in Indonesian society is the Book of Nurul Burhani by KH Muslih bin Abdurrahman Mranggen Demak and the Book of Jawahirul Ma'ani by K.H. Jauhari Umar Pasuruan. Both sides of the same content explain the hagiography or biography of the history of the most popular Sufi figure, Sheikh Abdul Qadir al-Jailani. The second is also widely practiced by practitioners who come from various circles and backgrounds. Interestingly, in addition to being written by two ulama from the Archipelago, the book has a different historical back- 
Moh. Ashif Fuadi: Comparative Study of Manakib Nurul Burhani Book with Jawahirul Ma'ani and The Teachings of Sufism... (page 243-265)

ground where K.H. Muslih and K.H. Jauhari Umar chose a different spiritual experience (Muhsinin, 2012: 38).

This paper intends to further review the comparative review of the book of manakib in terms of historical studies and its content. In addition, they also want to know the location of the similarities and differences of each even though the two have similar hagiographic plots in reading the history of alJailani. This paper also wants to emphasize the analysis of Sufistic content to understand to the public that in their respective articles, there are Sufism in the form of moral and ethical values that somebody can apply in daily life.

\section{B. Research Methods}

According to Danandjaja, the reference sources in library research can be done by analyzing articles, books, and writing sources that are still relevant to the theme (Danandjaja, 1997: 87). Then to get it, somebody can accurate analysis results can be done interpretation analysis to uncover the purpose and answers to the research problems raised. This paper uses library research with an analytical approach to historical-comparative studies by comparing historical studies and the content of each book. To see the profile of hagiography, we can use a 5W 1H (who, what, where, when, why, and how) analysis knife to show a comparison map between the text of Nurul Burhani and Jawahirul Ma'ani. In addition, the emphasis of content analysis will show how the similarities and differences in each article that somebody will find elements of novelty and meaning that have not been revealed. Research with literature studies is obtained by collecting hagiographic data related to the object, techniques, and literature methods by multiplying the literat ure and previous research. In contrast, the presentation of data uses descriptive qualitative methods.

\section{The Profile of The Author Hagiography Book And The History of Its Writing}

\section{Profile K.H. Muslih and the Beginning of Writing Manakib Nurul Burhani}

K.H. Muslih Mranggen was born in Mranggen Demak, Central Java in 1908 AD to K.H. Abdurrahman and Hj. Shofiyyah. In another opinion, he was born in 1914 A.D. refers to the KTP (residence identification card) that 
became the family archive. Some sources mention that his nasab (descendants) from the father up continued with Sunan Kalijaga. While from his mother, his nasab continued to Raden Patah Brawijaya V son. As a child born in the middle of a religious environment, he first got a direct education from his father, K.H. Abdurrahman ibn Kiai Qosidil Haq. His father taught various groups of typical sciences studied in pesantren ranging from the book of nahwu, shorof, manthiq, balaghah, tawhid, fiqh, Sufism, and so forth (Yusuf, 2020: 6).

During his development and his father, he also taught to ulama of Nusantara, namely K.H. Maksum Lasem, K.H. Zubair (father of K.H. Maimoen), K.H. Imam Sarang, K.H. Ibrahim Brumbung Mangkang Semarang, K.H. Dimyati Termas, and K.H. Abdul Latif Banten. He also continued his education in Haramain under sheik Yasin al-Fadani in Makkah (Yusuf, 2020: 24). From these ulama, Kiai Muslih grew into a strong person and mastered various religious sciences, including the world of order. According to Martin van Bruinessen, in the world of the order, he is known as one of the mursyids of the Qadiriyah wanaqsyabandiyah (TQN) order that pledged allegiance to Sheikh Abdul Karim al-Bantani. In addition, there are also other figures mursyid TQN with him namely K.H. Mustain Romli Rejoso Peterongan Jombang, Abah Anom Suralaya, Pagerageung, Tasikmalaya, and also K.H. Thohir Falak Pagentongan Bogor (Bruinessen, 2015: 425).

In addition to building the field of order, K.H. Muslih also nurtured one of the pesantren in Demak, Pondok Pesantren Futuhiyyah, and mastered various scientific fields ranging from Arabic grammar nahwu, shorof, and mantiq arudh, balaghah, fiqh, tafsir, hadith, Sufism, and order science. With the various disciplines he mastered, he made a prolific cleric, especially in the field of Sufism and order such as Futūhatu al-Rabbāniyyah, Umdatu al-Salik, Wasāilu Wushūli al-'Abdi Ilā Maulāhu, Yawāqi al-Tsāni fỉ Manāqibi alSyaikhi Abdul Qadir al-Jailani, al-Nūrul Burhani fî Tarjamati Lujjaini al-Dāni fii Dzkri Nubdzatin min Manāqibi al-Sheikh Abdul Qadir al-Jailāni. In addition, he also produced works in the field of tawhid, namely Inārotu adzDzulam, Matan al-Futūhiyyah, Iqdu al-farāid fî Syarhi Lubbi al-'Aqāid. In the field of jurisprudence, there is also the work of Inārot al-Daijur wa al-Duja fí Nadzmi Safīnati al-Naja, Taudhīh al-Tarājih fì Sholāti al-Tarāwih. While in other areas, there are works containing languages and prayers such as Hidàyatu al-Wildān, Tsamrotu al-Qulūb, Dalāil al-Khairāt, Munajat, Nasru al-Fajri fī 
Moh. Ashif Fuadi: Comparative Study of Manakib Nurul Burhani Book with Jawahirul Ma'ani and The Teachings of Sufism... (page 243-265)

Tawassuli bi Ahli al-Badr (Yusuf, 2020: 131).

K.H. Muslih was so significant that he contributed to the struggle for independence against the Dutch and Japanese by becoming a Hizbullah army member, and K.H. Abbas from Pesantren Buntet Cirebon became a force of Hizbullah warriors in Semarang and surrounding areas (Yusuf, 2020: 61). In addition, he also became one of the founders of Jam'iyyah Ahli Thariqah alMu'tabarah (JATM) in 1957 at Pesantren K.H. Chudhori API Tegalrejo Magelang Central Java with K.H. Chudhori, K.H. Nawawi Berjan Purworejo, K.H. Mandzur Temanggung, K.H. Masruhan Mranggen Demak and an affiliated Regent of Grobogan Andi Patopoy from NU (Nahdlatul Ulama). In its management structure, JATM experienced several periods of leadership Rois (leader of JATM) ranging from K.H. Baidlowi Lasem in 1958, K.H. Hafidz Rembang in 1963, K.H. Arwani Kudus in 1968, K.H. Musta'in Romli Rejoso Peterongan Jombang in 1973. In its development, JATM experienced adjustments due to political insistence so strong during the new order that it experienced internal dynamics and changed its name to JATMAN (Jam'iyyah Ahli Thariqah al-Mu'tabarah An-Nahdliyyah) starting in 1979 until now by Habib Luthfi bin Yahya. K.H. Muslih appeared as Rois, the first to play a role in developing JATMAN until the end of his life in 1981 until Moh. Masrur is referred to as Syaikhul Mursyidin (Masrur, 2014, p. 270). K.H. Muslih died in Syawal 1981, inherited Pesantren Futuhiyyah, and was buried in the Ma'la Makkah Mukarromah around the tomb complex of the Prophet's wife Khadija al-Kubro adjacent to the tomb of Asma' Binti Abu Bakar As-Sidiq (Yusuf, 2020: 83).

In the practice of manakib, Nurul Burhani is among the most widely read by his practitioners as stated in the outer cover described by K.H. Muslih Mranggen that the book's content is an excerpt from the book of al-Lujaini al-Dāni by Sheikh Jakfar al-Barzanji (1690-1764) as the book of al-Faidhu alRahmān Majelis al-Khidmah K.H. Asrori al-Ishaqi who also quotes from the book of al-Lujaini al-Dāni (Yusuf, 2020: 135).

There is an interesting historical study at the time of writing the book Nurul Burhani which is not known by many parties sourced from Mrs. Nyai Hj. Umi Sa'adah, wife of Kiai Muslih, who told that at the time, the two are going to K.H. Maksum, better known as Mbah Maksum Lasem in 1960, the early days of marriage, to just tabarruk ask for prayers so that his marriage gets blessings. When K.H. Muslih confronted Mbah Maksum, his wife from Sema- 
rang liked to read manakib Sheikh Abdul Qadir, but the book of manakib read is not the same as most pesantren. Then Mbah Maksum gave him a solution to compose his manakib book. After the event, K.H. Muslih began to study the book of manakib and guided from the book of al-Lujain al-Dāni, then given syarah (commentary and explanation), then became the book of manakib Nurul Burhani. Even told about Sheikh Abdul Qadir al-Jailani when K.H. Muslih is composing Nurul Burhani (Yusuf, 2020: 360).

The first book of manakib Nurul Burhani K.H. Muslih bin Abdurrahman Mranggen completed Rabi'ul Awal 1382 H coincided with 1962 A.D. as a complete finisher book manakib Nurul Burhani was completed in the month of Sya'ban $1383 \mathrm{H}$ coinciding with $1963 \mathrm{AD}$. to disseminate it. The book was printed by the publisher Toha Putra of Mangkang Semarang and spread throughout the Archipelago, especially nadliyin and pesantren (Yusuf, 2020: 135).

\section{Profile of K.H. Ahmad Jauhari Umar and The History of Writing Manakib Jawahirul Ma'ani}

K.H. Jauhari Umar has the nickname Muhammad Bahri, born in Dukuh Nepen, Krecek Village, Pare Kediri on Friday Legi on August 17, 1945, before the $02.00 \mathrm{am}$. His father is K.H. Muhammad Ishaq, is still connected with Sunan Gunung Jati Cirebon. His mother's path is also associated with the great cleric Kiai Ageng Muhammad Besari Tegalsari Ponorogo (Mansyur, n.d.: 5). His childhood received rigorously religious education from his parents directly by memorizing the Qur'an at the age of 11 years and the fiqhpatterned book of taqrib by Abu Shuja'. The habit of tabarrukan his parents intercede to the ulama delivered to Muhammad Bahri small to learn to Kiai Syafaat Blok Agung Banyuwangi and K.H. Dimyati Pandeglang Banten known as Abuya Dimyati (Mansyur, n.d.: 6).

K.H. Jauhari Umar was married to one of the's daughters K.H. As'ad Pasuruan named Nyai Saidah. From the marriage in 1983, given three children, Namely Salahudin, Ali, and Sultan. The three sons are now continuing the struggle of K.H. Jauhari Umar. In another marriage, she was also married to the daughter of one of the Kiai from Blitar named K.H. Yasin (Sholahuddin, n.d.: 12-13).

In establishing Pesantren Darussalam in Tanggulangin Village, Kejayan Subdistrict, Pasuruan Regency, he obtained waqf land to be a man named Haji 
Moh. Ashif Fuadi: Comparative Study of Manakib Nurul Burhani Book with Jawahirul Ma'ani and The Teachings of Sufism... (page 243-265)

Muhammad. Construction began in 1998 with the surrounding community by establishing a mosque first. Because for about four years, the mosque that was built that is not complete, following the advice of Kiai Hasan Mangli Magelang, then the mosque was then torn down. Then Kiai Jauhari Umar rebuilt a mosque and madrasah with the students until they finish (Sholahuddin, n.d.: 15).

After the construction of pesantren was completed, the students from various regions began to arrive and more and more. One of the books studied in pesantren is Abu Syuja's taqrib which he read from a young age. It is based on the spiritual experience of Kiai Jauhari Umar when visited by the author and given the yellow book taqrib until the book is still stored until now. Furthermore, many Kiai Jauhari Umar's students became religious figures in various regions (Sholahuddin, n.d.: 16).

One of the customs of Kiai Jauhari Umar is sowan (visiting ulama/kiai) with the aim of asking for prayers so that his life gets blessings. Among the Kiai who be visited by him are Kiai Abdul Hamid Pasuruan, Kiai Kholil Sidogiri, Kiai Syafaat Blokagung Banyuwangi, Kiai Hayatul Maki Kediri, Kiai Marzuqi Lirboyo, Kiai Maksum Lasem, Kiai Baidlowi Lasem, Kiai Masduqi Lasem, Kiai Imam Sarang, Kiai Chudhori Tegalrejo Magelang, Mbah Dalhar Watucongol, Mbah Dimyati Pandeglang Banten and others. One of the prayers offered by Mbah Abdul Hamid Pasuruan that kiai Jauhari Umar will become a rich cleric and can perform hajj many times for the first time in 1983. After a long spiritual journey and gaining knowledge from the visiting Kiai, the K.H. Jauhari Umar collected these practices then became a group of Jawahirul Hikmah practices (Mansyur, n.d.: 7).

In some phases of his life, Kiai Jauhari Umar had experienced the indecision of entry into the well-known anti-tradition and carries textualist jargon back to the Qur'an and sunnah even he briefly served as vice chairman of the Assembly tarjih in Kaliwungu. But over time, through some advice when meeting the kiai-kiai above, Kiai Jauhari Umar returned to the understanding of Pesantren Nahdlatul Ulama Kiai. That belief is further reinforced by the inspiration he received through dreams when meeting with large kiai such as Kiai Abdullah Sakin, Kiai Yasin bin Ma'ruf Kedunglo Kediri, Sayid Maksum Badung Madura, and Kiai Abdul Hamid Pasuruan. They explained that the teachings that somebody should take are Ahlussunnah Wal Jamaah an- 
Nahdliyah (Sholahuddin, n.d.: 6-8). On Saturday night around 00:55 on 20, September 2003 coincided with 23 Rojab 1424 H K.H. Jauhari Umar died in Pasuruan and was buried in the mosque complex Pesantren Darussalam Pasuruan left bequeathed pesantren and intellectual works of Amaliah Jawahirul Ma'ani (Mansyur, n.d.: 79).

Related to the history of the writing of the book Jawahirul Ma'ani, there is a difference between it with Manakib Nurul Burhani, which is the excerpt of the parent book al-Lujaini al-Dāni. The difference lies in the origin of Jawahirul Ma'ani, which begins from the author's spiritual journey. K.H. Jauhari Umar, on his journey, made a pilgrimage to all the tombs of the guardians in Java. As was the education of his parents, K.H. Jauhari often make pilgrimages from one place to another from guardians or people who are still alive or dead. Inspiration or inspiration appeared when he made a pilgrimage from Madura, Banyuwangi to the western end in Banten. The process of futuh (connecting to God) happened when he made a pilgrimage to the Madura tomb of Sheikh Kholil Bangkalan. At that time, he consciously met the grandson of Sheikh Abdul Qadir al-Jailani named Sayid Syarifuddin. Through that process also happened Jawahirul Ma'ani diploma from Sayid Syarifuddin to K.H. Jauhari Umar to be practiced as widely as possible to obtain the blessings of the afterlife (Mansyur, n.d.: 15-16).

\section{Comparative Study And Content Analysis Of The Content Sufism In The Book Of Manakib}

\section{Content Analysis of Nurul Burhani}

In creating the book of Nurul Burhani, K.H. Muslih tries to display a more scientific writing style by providing footnotes. The purpose is to provide information related to the grammar rules of nahwu, shorof, and explain the meaning of the editor of matan (content) in the book of al-Lujaini al-Dni so that it is expected to provide understanding to the practitioners of manakib and lovers of Sheikh Abdul Qadir al-Jailani. The evidence presented by K.H. Muslih is derived from the mu'tabar (recognized) book and a reliable hadith to strengthen further the arguments and arguments in understanding the figure of al-Jailani with the teachings of Sufism.

In this case, Misbahkhul Khaq argues otherwise that the hadith in the book of manakib is generally still found hadith dhoif (weak), and there are 
only a few who sahih (strong argument). Still, in terms of matan (content), the majority is not contrary to the Qur' an, so its stat us becomes legitimate (Khaq, 2015: 107). Nurul Burhani is a nukilan from the al-Lujaini al-Dāni fí Dzkri Nubdzati Min Manaqibi al-Sheikh Abdul Qadir al-Jailani part two. It consists of eight articles (parts): the first part of the sentence taqridz (compliments) from Habib Soleh bin Idrul al-Habsyi agreed by K.H. Dimyati Kedawung Comal Pemalang. This section emphasizes how important a person loves and follows the teachings of the guardian as written in the book of manakib to obtain the afterlife's success. The lovers of God mentioned in manakib are the most fearful of Allah, istikomah, have the perfection of morality, and they are a representation of al-Sawādul al-A'dzām (the majority group) in the concept of Ahlusunnah. Hence, it is very feasible to mingle in it (Muslih, 2001: 1). In the opening of Nurul Burhani, Kiai Muslih started with tawasul doing prayers through the intermediaries of the prophets and the righteous, primarily through the intermediary of Sheikh Abdul Qadir al-Jailani, tahlilan and continued reading manakib (Muslih, 2001: 3).

First, in this section, by reading the book of al-Lujaini al-Dāni, it begins with reading basmalah, hamdalah, and sholawat nabi. Then, explained the description of the book of manakib written by Sheikh Ja'far al-Barzanji, which contains the practices and teachings and position of Sheikh Abdul Qadir al-Jailani. When the guardian's name is mentioned, it will bring down Fuyüdhotu al-Ilähiyyah in the form of spills and an abundance of blessings to its readers. After that, it explains how the genealogy of Abdul Qadir al-Jailani continued to the Prophet Muhammad through Sayid Hasan, son of Fatimah (Muslih, 2001: 5-15). Furthermore, Qosidah Nasabun and Qosidah Yassir Lana contain the glory of nasab al-Jailani, which continues to Rasulullah through Sayidina Hasan (Muslih, 2001: 15).

Second, this section explains how al-Jailani's birthplace in Jilan city near Tabaristan on 1 Ramadan $471 \mathrm{H}$. In his childhood, al-Jailani studied jurisprudence to Sheikh Abil Wafa, Sheikh Abil Khottob, and Sheikh Abil Husein. While in the field of moral learning to Sheikh Abi Zakaria. In the world of alJailani, order pledged allegiance to Sheikh Hammad al-Dabbas and Sheikh Abi Said al-Mubarok. Furthermore, al-Jailani conducted a suluk (spiritual practice) to control his passions to go out from Iraq by wearing a typical Sufi robe and khirqota al-Sufiyyah (a piece of cloth) for twenty-five years until it reached the mortal level jadzab. In Sufi world terms as considered crazy scorned by 
many people until al-Jailani can control his nafsu (lust) with everything guarded by Allah (Muslih, 2001: 20).

Third, this section explains the beginning of his meeting with the Prophet Khidr in Iraq, and he taught the Prophet Khidr by settling there until his teacher revisited him. al-Jailani, in the process of practice his tirakat (cleaning of the soul), is a person who sleeps a little and perpetuates wudhu' to focus on taqarrub and reach the tomb of 'allamah (a very clever person) so that he became a famous cleric in his day al-Jailani explores thirteen branches of science: Tafsir, Qur'an, khilaf, ushul, kalam and fiqh, nahwu, qiro'ah/ tajwid, huruf, 'arudl, Badi,' ma'aani, bayan, mantiq and Sufism. He was a follower of the madzhabs of Imam Shafi'i and Hambali. Once when asked about the complicated issue of triple divorce vows that the husband and wife dropped were to remove, someone had to perform worship that no one else was doing at that time. Al-Jailani replied that he had to go to Makkah to wait for the quiet of people to perform tawaf worship seven times until his oath was released (Muslih, 2001: 28).

Fourth, in this section, it is explained that Shaykh al-Jailani scolded the thoislan shirt, which is a robe whose clothes cover the face and head as a sign of a cleric's shirt. He opened his veil and spoke in a clear and loud voice in a state of teaching and receiving guests. One of the testimonies of Shaykh Abu Abdillah al-Harawi said that when he was a khodam (servant) of al-Jailani for 40 years, he always saw al-Jailani keeping his wudu', even when he wanted to pray shubuh often using wudu' prayer isyak. Shaykh al-Jailani finished doing isyak prayers then entered the room for mujahadah (spiritual effort against lust) until the time of Shubuh by multiplying nafilah (sunnah) blessings and reading asma a'dhom (the name of the great Allah). Even the King of Baghdad could not see him when he had done so. In another testimony, Shaykh Ibn Abil Fattah said that Sheikh al-Jailani also gave obvious signs to Sufism experts, especially mursyids. They must have mastered three things: mastering the science of ulama, understanding the science of government, and master the science of wisdom (Muslih, 2001: 38).

Shaykh al-Jailani often asks his students questions about Sufism and order, but all of them were successfully answered, indicating his knowledge's height. At one point there was a beam of light appeared in the sky. Somebody heard the voice from the light "O Abdul Qadir, I am your Lord, I have allowed 
you to do things that are forbidden," then spontaneously al-Jailani replied; "In the name of Allah, get out of the cursed Shaytaan (evil)!" then a beam of white light turned into a dark cloud until a voice was heard: "O Abdul Qadir, because of the breadth of your knowledge, then congratulations from my misguided actions, how many seventy members of the order are lost as this incident." After surviving the incident, al-Jailani praised God, who had willed so, when asked how he knew it was a shaytan? Al-Jailani replied: "From his speech that allows from something that is forbidden because God never commanded evil." (Muslih, 2001: 43).

Fifth, this section explains that al-Jailani does not like to glorify people who are domiciled like kings and other officials to glorify Sufism not to be easily tempted with the world. A king came with an apple that was covered in blood after being peeled. It shows the wrongdoers of the official who sacrificed human blood. Shaykh al-Jailani also appreciates the poor, where the position of the poor who want to be patient is nobler than the grateful rich. Likewise, a grateful poor man is more dignified than both, let alone the position of a poor person who will be patient and grateful more important than all. Concerning Bala (temptation), al-Jailani explained the coming of reinforcements, calamities, or trials. (Muslih, 2001: 47). All of it is by God's will so that all are faced with patience.

Sixth, this section explained some karomah (spiritual advantages of wali Allah) owned by Sheikh Abdul Qadir al-Jailani. The first karomah that he never got a fly signifies how awake the body of Sheikh Abdul Qadir al-Jailani he got because it inherited the sanctity of his grandfather Prophet Muhammad. Then, when Sheikh Abdul Qadir al-Jailani held a science assembly, the fall of Emprit bird (the name one of bird) droppings suddenly fell. And he saw the bird, and the bird fell and died. One day, a mother came to pesantren alJailani to see her son who was studying there. The mother was surprised to see her son's thin-looking body as if he had never been fed. He wanted to meet Sheikh Abdul Qadir al-Jailani directly will ask about it. Then around Sheikh Abdul Qadir al-Jailani, some chicken bones from the leftover food have just been eaten. Then Sheikh Abdul Qadir al-Jailani put his hand on the shattered bones and said, stand up, $\mathrm{O}$ bones. Then instantly, the bones were turned into chickens if crowing Là Ilāha Illallah Muhammadur Rasulullah Sheikh Abdul Qadir Waliyullah (Muslih, 2001: 56). It shows that his son was still in the process of tirakat, who still needs to practice concerned. 
One day in, an eagle swirled over the clouds while making a loud noise and then looked at the bird. Instantly the bird that sounds loud and interferes with the learning process falls and is in a state of a severed head. Then hailed by al-Jaelani by saying bismillah, the bird came back to life. Some mob robbed the story of the traveler who is traveling, then Syekh Abdul Qadir al-Jailani when taking wudu', he threw his two slippers in turn. A few days later, komplen (slippers from wood) turned out to put against some mob and robbers. A man from Isfahan came to Sheikh to treat someone affected by the jinn. Then the Sheikh explained that the person was affected by the disturbance of the genie from the Sarondib cave. His name was Khonis. He said, Khonis, through the wasilah of Sheikh Abdul Qadir al-Jailani, you should never return, or somebody will destroy you. When there are guests from Jilan in the assembly of Sheikh Abdul Qadir al-Jailani, there is a jug that does not face the Qibla. At that time, the servant next to him denied that. Suddenly the servant fell and died, and the jar faced itself to the Qibla. When Sheikh Abdul Mudhofar was about to trade, he had previously met Sheikh Hammad. So by Sheikh Hammad, He is forbidden to travel so as not to be wretched. But, when meeting with Sheikh Abdul Qadir al-Jailani, he was allowed to travel. While asleep, he dreamed of being killed instantly. He woke up and told Sheikh Hammad, who explained that thanks to the prayer of Sheikh Abdul Qadir, somebody only killed him in a dream, not in the real world. The story of a man who limped then given a blessing by Sheikh Abdul Qadir so that the person became healthy again in a state of flying as if the greatness of a person is nothing compared to Abdul Qadir al-Jailani (Muslih, 2001: 60).

One time Sheikh Abdul Qadir al-Jailani went out of the house, followed by Sheikh Abul Hasan al-Baghdadi. He saw when the Sheikh went somewhere by going to six people who were gathered to offer something. One person was taken out in a state of death. Suddenly the Sheikh brought others to replace the seven wali abdal (successor). He was a convert to the Qustontinid State of Christianity. Once there was a king Abul Mudhoffar came to face Sheikh Abdul Qadir al-Jailani with ten bags containing money, but he refused. Because it still forced the acceptance of two bags after it was opened turned into the blood that instantly made the king ashamed to repent. In another momentum where it is not the fruit season, the king wants apples from the supernatural. Then two apples were taken by Sheikh Abdul Qadir al-Jailani. One apple is held by al-Jaelani, who smells as fragrant as a shot, while another 
apple received by the king with an unpleasant and foul smell indicates that the king still commits an injustice. There are many of his karomah that have not been mentioned (Muslih, 2001: 87).

Seventh, in this section, explain the figure of Sheikh Abdul Qadir alJailani teaches to be grateful as the word of God in the letter ad Dhuha last verse. Surely the one who has met Sheikh Abdul Qadir al-Jailani will get help from him later when he gets the punishment of the grave. He also mentioned Sheikh Husein al-Hallaj, who was considered deviant. If al-Jaelani lived then, he would save him so that it did not slip. Sheikh Abdul Qadir al-Jailani will also protect from the path of straying to his friends, disciples, and lovers until the Day of Resurrection, both living and dead. Sheikh Abdul Qadir al-Jailani is the guardian who has a sea of knowledge like an infinity ocean. Sheikh Abdul Qadir al-Jailani has mature saw skin, chest area, slim body, bushy beard. His voice is loud and melodic, easy to shed tears because of his fear of God. His prayer is mustajabah (granted), good manners, excellent nasab origin, and derivatives, always acting on the truth. This figure likes to give help, easy to give to the needy, guardians who ma'rifat, his order following tawhid, his heart is always covered with dhikr, sincere in every act as a servant of God. His soul is always connected with God at the time of remembrance and carrying out the laws of God. The glory and privileges and karomah of Sheikh Abdul Qadir al-Jailani are still reflected in his daily attitudes and behaviors. He died on 11 Robiul ends of 571 Hijri at the age of 91 years and was buried in Bebul Aroj Baghdad, Iraq, which until now his tomb is visited by many pilgrims from abroad (Muslih, 2001: 87-106).

Eighth, in this section, is the final part of the book that contains the closing prayer through tawasul to the guardian Qutub Sheikh Abdul Qadir alJailani. In addition, there are also two qosidah (Arabic songs) containing praise and prayer the first Qosidah 'Ibādallah Rijālallah, and the second is Qosidah Ya Arhamar Rāhimīn by Habib Abdullah bin Husain bin Thahir and Qosidah Ya Rohmatallahi Zuri by Habib Abdullah bin Alawi al Haddad (Muslih, 2001: 106-127). In the book, K.H. Muslih's footnote, the original text al-Lujaini al-Dni, namely Sheikh Ja'far al-Barzanji is a Sunni figure and not a Shia people have alleged. Furthermore, Sheikh Ja'far is the mufti madzhab Imam Syafi'i, followed by the majority of the population of Indonesia. Besides, he also explained other statistics such as Sheikh Ja'far Shodiq, who is also considered Shia, even according to K.H. Muslih quoted from the 
book that mu'tabar explained that Sheikh Ja'far Shodiq is a Sunni who is still a descendant of Rasulullah.

\section{Analysis of The Content of Jawahirul Ma'ani}

In the earliest part of Jawahiul Ma' ani explains the virtue of reading the first book. Whoever wants to practice Jawahirul Ma'ani manakib should see the information on page 43 of this book. Second, if it is kept at home, thieves and robbers cannot enter the house, and if it is brought as an azimat (amulet), it will be easier to seek sustenance because, in this book, there is Ismu alA'dhom to be well guarded (Umar, n.d.: 2).

Then, it is explained about the description book has been allowed by Muslims and the procedure of practice. Kiai Jauhari Umar started by reading bismillah, alhamdulillah, and sholawat on the Prophet, first, manakib Sheikh Abdul Qadir al-Jailani and prayers, wirid-wirid, asma (name of God) that is here has been graduated to all Muslims. Second, as for the efficacy and benefits of reading this book, we will explain at the end after the recitation of prayer. Third, if you are going to practice, it should begin by reading tawasul to the prophets, aulia, ulama, and solihin, as stated in the book. Then read sholawat 11 or 100 times, then read sholawat burdah (maula ya sholli wasallim daiman abada) until the end of 11 or 21 times. Then, read Jawahirul Ma'ani manakib until it is finished (Umar, n.d.: 3-6).

Jawahirul Ma'ani's book consists of nine sections containing the hagiographic Sheikh Abdul Qadir al-Jailani. First, in this section, Kiai Jauhari Umar began reading manakib by reading hamdalah, sholawat to the Prophet and his family and friends. It also explains Sheikh Abdul Qadir al-Jailani as the guardians of Qutub (spiritual center) and al-Ghoust (wali who asked for help), the guardians who can help. Then it is also explained how the genealogy of Sheikh Abdul Qadir al-Jailani from the father's path continues to the Prophet Muhammad through Sayyid Hasan, son of Fatimah. Meanwhile, the finger of his mother's path continued to the Prophet Muhammad through Sayyidina Husein (Umar, n.d.: 9-12). Overall there are many similarities in the first part of Nurul Burhani and Jawahirul Ma'ani as written above. But there is also a slight difference, especially in the connection of nasab in Jawahirul Ma'ani mentions the genealogy of Sheikh Abdul Qadir al-Jailani through the mother's path that is not mentioned in the book of Nurul Burhani.

Secondly, this section in the book of Jawahirul Ma' ani also explains how 
the birth of Sheikh Abdul Qadir al-Jailani was written in Nurul Burhani. He also explained the process of educational-Jailani to his teachers, both jurisprudence, morals, and area of the order. But there is little difference wherein the chapter in the second part of the book explains how important one is to keep purity in an assembly and how the conditions for being mursyid (spiritual teacher) and the advice to keep lusts. While in the book of Nurul Burhani it the author is revealed in the fourth and fifth parts. Another difference is that in the book of Jawahirul Ma' ani, there is no mention of the process of the wandering of Sheikh Abdul Qadir al-Jailani when he came out of Iraq wearing a Sufi robe from a piece of cloth for 25 years (Umar, n.d.: 12-14).

Third, this section's sharp difference explained that when the Prophet Muhammad was mikraj (journey for Aqso to Sidratul Muntaha) to the Allah heavens was welcomed by the prophets and guardians. So when the Prophet was about to ascend to the 'Arsy(throne), Allah sent the spirit of Sheikh Abdul Qadir al-Jailani to put the foot of the Prophet Muhammad on his shoulder, saying that this is your son from the descendants of Sayidina Hasan named Abdul Qadir. The Prophet Muhammad said that if there was no cover of the Prophet, perhaps al-Jailani continued. The Prophet continued saying that it is very fortunate for the one who sees the Prophet and the sheik then sees it and so on up to 27 levels. The Prophet Muhammad made al-Jailani a minister in the world and, at the end and put both feet on the shoulders of Sheikh Abdul Qadir al-Jailani, and the soles of the sheik's feet were on all the shoulders of the guardians with no pride and hubris. Nurul Burhani is not mentioned in this section of the book, so there is a striking difference (Umar, n.d.: 15-17).

Fourth, this section is also very different from the one in Nurul Burhani. Kiai Jauhari Umar explained that there was a follower of Prophet Jesus who was arguing with his student Sheikh Abdul Qadir al-Jailani. The Prophet Jesus followers said that the Prophet Jesus's position is higher than the Prophet Muhammad because of the ability or miracles of the Prophet Jesus, who can revive the dead. When the two faced Sheikh Abdul Qadir Jaelani, he explained that he was not a prophet but merely a follower of the Prophet Muhammad. If a follower can also revive the dead as The Prophet Jesus Is a Christian, will also believe the position of the Prophet Muhammad is nobler. AChristian said yes. Then they set off for the cemetery where a singer was buried. Al Jailani said the Prophet Jesus revived the dead with qum bi idznillah (rise according to Allah's permission). Then Al Jailani told the Christians that the one buried 
inside was a singer; if I could wake him up in a state of singing, then whether you would believe. By chanting qum bi idznì (rise according to my permission), the singer buried inside then rises and revives by chanting. Seeing this phenomenon, a Christian then recognized the virtues of Sheikh Abdul Qadir al-Jailani and believed that the Prophet Muhammad was more critical than the Prophet Jesus to convert to Islam (Umar, n.d.: 17-20).

Fifth, he wore his shirt in green robes in this early part and climbed on a donkey wearing headgear on it. He said while sitting on a chair with clear and firm words. It is the same as that shown in the fourth part of Nurul Burhani. The difference lies in explaining the story afterward. When someone has a hard heart, it will be made soft by al-Jailani as if he already knew everything. When Sheikh Abdul Qadir al-Jaelani passes through a gathering on Friday, people will stop and pray through his intermediary. Once there was a group of people who challenged Sheikh Abdul Qadir by carrying two baskets that were closed. Then he was asked to guess what the basket was. Quickly Sheikh Abdul Qadir put his hand in one of the baskets and saw the rice field containing a paralyzed boy. Then he ordered his son Sheikh Abdul Rozak to open the basket turned out to be actual contents is a paralyzed boy. Then Sheikh Abdul Qadir held the child's hand and said, "Stand up, immediately the paralyzed can stand. He then opened basket number two. Shaykh put his hand on it and said the contents were normal children did not hurt one bit. Then the child would immediately stand and run, but the Sheikh asked to calm down and sit down so that the event caused the hordes who wanted to test repented (Umar, n.d.: 20-22). So, the equation is just at the beginning of the section, and after that, everything is different.

Sixth, this section explains that Sheikh Abdul Qadir never exalted a person because his wealth was calm, nor did he gather the rulers. Sometimes the Sheikh walked over the Clouds and was witnessed by his disciples. One time, a woman came to Sheikh Abdul Qadir to visit her son, who was studying. But the woman found her son looking thin and pale, unlike before. Next to her son, there is food, just plain bread. Then the woman protested against the Sheikh and found the bones of the chicken used by the Sheikh. She said, "O Shaykh, eat chicken meat, and my son eats wheat bread. Then he put his hand on the chicken bones and said, O chicken, stand by Allah's leave, and revive the bones in a state or district. Then the bones rose again and crowed Là ilāha illallah Muhammadur Rasulullah Sheikh Abdul Qadir Waliyullah. Shaykh 
Abdul Qadir said if your son can do this, he will eat anything (Umar, n.d.: 2224). There are many similarities with the book of Nurul Burhani in almost all parts. Including the speed of the section about the story of cut-off neck eagle or alap-alap is the same as Nurul Burhani in the sixth part. It's just that the slight differences that appear at the beginning are related to the way al-Jailani views in glorifying the rich, wherein the book of Nurul Burhani is in the fifth part.

Seventh, this section explains Sheikh Abdul Qadir al-Jailani has mature saw skin, chest area, slim body, bushy beard, loud voice, and musical. It is also the same as it is written in the seventh part of Nurul Burhani. The difference lies in the phrase that follows. It tells of the blossom and integrity of the Syeikh Abdul Qadir al-Jailani between the heart and the soul so well advertised and logic that emanates from the sunah and divine decree. It makes many people wonder. There is a story of a good woman about to throw a hajat (wish) in a cave. But there is a fasiq (insubordinate) who intends badly to him. The woman said, "Abdul Qadir help me three times when Abdul Qadir came down from above and beat the criminal with his two wooden slippers to death (Umar, n.d.: 25-27). So in this section, there are more redactions than similarities except for the explanation of al-Jailani's physicality.

Eighth, Sheikh Abdul Qadir al-Jailani easily wept because Allah, so authoritative and asked mustajabah (granted), and morals are very noble. The scent of his body is very fragrant. He is also a figure who always avoids reprehensible deeds and performs good deeds. Kanjeng Sheikh would be very sorry if he made a mistake, even if accidentally. He always asks God for help and is also very generous to people, even at the expense of one of his two garments. He always trained himself to trust and did not like to show off his deeds to people. Istikomah in learning, closer to God, and have high obedience to reach maqam ma'rifat (level of ma'rifat) only to get His ridho. He is a dhikr member, mukasyafin (the disclosure of veils) by carrying out sharia and fact. As written in the book of Nurul Burhani, people who pass through his madrasah will get his help. Especially for the lovers, they will get the happiness of the hereafter and die to bring faith and Islam and perfect pleasure (Umar, n.d.: 27-29). In this section, there are many similarities with the book of Nurul Burhani, especially the seventh part.

Ninth, As written in the book of Nurul Burhani, the Sheikh will always tell the goodness of the blessings given by God. He said, "Every guardian is 
on the feet of the prophets, and I am on the soles of my grandfather's feet, the Prophet Muhammad, and the Prophet Muhammad himself will not lift the soles of his feet unless I have placed the soles of my feet on the palm of alJailani. Indeed there is no right way to obtain it except the Prophet. Men and jinn have the like of them, and I am their leader. My Lord, my help will overshadow my disciples and lovers from the east end to the west end. I am the one who will help my best friend, my dear student, with the grasp of my hand, both alive and dead. Furthermore, this article is almost the same as the seventh part of Nurul Burhani until the day's discussion where the death of the Sheikh, his age, and tomb sheik who many people from all directions always pilgrimage. Amin Allahumma Amin (Umar, n.d.: 30-34).

Tenth, this section contains prayers with the blessing of Sheikh Abdul Qadir al-Jailani and Qasidah 'Ibadallah. Then, when it comes to wasilah prayer, pause and mention the hope of prayer until finally, prayer (Umar, n.d.: 34-42). Furthermore, page 43 said Faidah Agung (great benefit) listed in the table as follows (Umar, n.d.: 43-48).

Table 1.

Fadhilah Book of Jawahirul Ma'ani

\begin{tabular}{|c|c|c|}
\hline No. & Fadhilah (efficacy) & Kaifiyah (ordinances) \\
\hline 1. & $\begin{array}{l}\text { Get the breadth of sustenance and } \\
\text { get the opport unity to perform hajj. }\end{array}$ & $\begin{array}{l}\text { Every day read this manakib five } \\
\text { times or } 11 \text { times for } 41 \text { days and every } \\
\text { night on the } 11 \text { th of Hijri month by } \\
\text { holding salvation and preceding it by } \\
\text { fasting. }\end{array}$ \\
\hline 2. & $\begin{array}{l}\text { To gain knowledge and to be } \\
\text { provided with ease in seeking } \\
\text { sustenance. }\end{array}$ & $\begin{array}{l}\text { Every day read wirid Ya Badi'u } 946 \\
\text { times, then read manakib. }\end{array}$ \\
\hline 3. & No economic delays & $\begin{array}{l}\text { Read this expected until khatam } \\
\text { (finished). }\end{array}$ \\
\hline 4. & $\begin{array}{l}\text { Get the breadth of sustenance and } \\
\text { karomah. }\end{array}$ & $\begin{array}{l}\text { Every night of the } 11 \text { th, Hijri held } \\
\text { congratulations according to ability then } \\
\text { read manakib. }\end{array}$ \\
\hline 5. & $\begin{array}{l}\text { Has many students and the } \\
\text { breadth of sustenance }\end{array}$ & $\begin{array}{l}\text { Each ba'da maghrib reads } \\
\text { Shollallahu 'Ala Muhammad } 100 \text { times } \\
\text { then reads manakib. }\end{array}$ \\
\hline 6. & $\begin{array}{l}\text { Mahabah, especially to loved } \\
\text { ones, to get more love. }\end{array}$ & $\begin{array}{l}\text { Read the letter al-Fatihah addressed } \\
\text { to the loved one } 11 \text { times, then read this } \\
\text { manakib after midnight. }\end{array}$ \\
\hline
\end{tabular}


Moh. Ashif Fuadi: Comparative Study of Manakib Nurul Burhani Book with Jawahirul Ma'ani and The Teachings of Sufism... (page 243-265)

\begin{tabular}{|c|c|c|}
\hline 7. & Make asma'oil or prayer oil. & $\begin{array}{l}\text { Read al-Fatihah } 101 \text { times, verse } \\
\text { seat } 41 \text { times, yasin } 4 \text { times, sholawat } 11 \\
\text { times and manakib once. }\end{array}$ \\
\hline 8. & $\begin{array}{l}\text { Given the saleable in opening a } \\
\text { business }\end{array}$ & Every day to read this manakib. \\
\hline 9. & $\begin{array}{l}\text { Able to realize and influence } \\
\text { society a lot in terms of goodness. }\end{array}$ & $\begin{array}{c}\text { Once a week, holding a } \\
\text { congregation of manakib. }\end{array}$ \\
\hline 10. & $\begin{array}{l}\text { Given the ability to be able to } \\
\text { quickly build houses, madrasah, } \\
\text { pesantren, mosques, and soon }\end{array}$ & $\begin{array}{l}\text { Every Friday night, salvation with } \\
\text { sweet dishes such as dawet, compote, } \\
\text { jenang, and every day is recited this } \\
\text { manakib. }\end{array}$ \\
\hline 11. & Gain & $\begin{array}{l}\text { By taking water bak (water place of } \\
\text { wudu) in the mosque the size of a kettle } \\
\text { and then recited manakib as much as } \\
\text { seven times, then whoever drinks the } \\
\text { water will not be injured alias does not } \\
\text { work with sharp weapons. }\end{array}$ \\
\hline 12. & Cure & $\begin{array}{l}\text { Saltwater that is recited manakib } \\
\text { Jawahirul Ma'ani will be efficacious to } \\
\text { cure all kinds of diseases. }\end{array}$ \\
\hline 13. & $\begin{array}{l}\text { The efficacy of quite a wind and } \\
\text { Qodamun Wahid so that it can run } \\
\text { fast. }\end{array}$ & 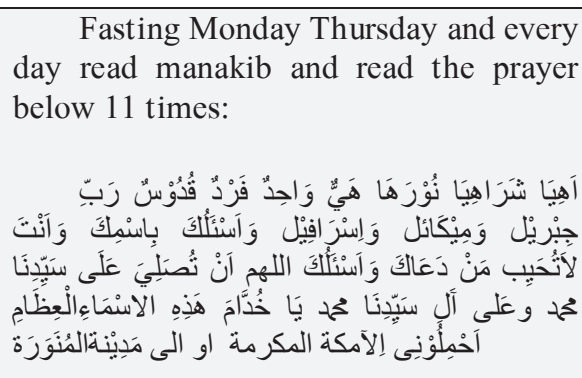 \\
\hline 14. & $\begin{array}{l}\text { Apply for a loved one or apply for } \\
\text { a job to get results. }\end{array}$ & $\begin{array}{l}\text { Read al-Fatihah's letter } 11 \text { times } \\
\text { specifically to the person who applied for } \\
\text { the proposed job and then read the } \\
\text { manakib. }\end{array}$ \\
\hline 15. & $\begin{array}{l}\text { Destroy enemies and conquer } \\
\text { them. }\end{array}$ & $\begin{array}{l}\text { After ba'da maghrib, read ya } \\
\text { qowiyyu ya matiin ikfi syarrodzolimin } \\
100 \text { times devoted to the intended } \\
\text { enemy, then read manakib. }\end{array}$ \\
\hline 16. & $\begin{array}{l}\text { To get a partner immediately } \\
\text { (mate). }\end{array}$ & $\begin{array}{l}\text { Starting with reading manakib then } \\
\text { using powder Insha Allah before three } \\
\text { containers will get a mate. }\end{array}$ \\
\hline 17. & Blessed for rice and money, & $\begin{array}{l}\text { Read the verse of the chair as many } \\
\text { as } 313 \text { times blown against the rice or } \\
\text { money, then read manakib. }\end{array}$ \\
\hline 18. & Get out of jail soon, and trouble & $\begin{array}{l}\text { Reading the manakib and doing the } \\
\text { safe as much as possible. }\end{array}$ \\
\hline
\end{tabular}


IBDA': Jurnal Kajian Islam dan Budaya

\begin{tabular}{|c|c|c|}
\hline 19. & $\begin{array}{l}\text { To quickly move up the } \\
\text { department }\end{array}$ & $\begin{array}{l}\text { A fter maghrib, recite Shallallahu } \\
\text { 'A la M uhammad } 100 \text { times, then repeat } \\
\text { the never before. }\end{array}$ \\
\hline 20. & $\begin{array}{l}\text { As a handle, Ismul A'dhom is } \\
\text { written as an amulet (mantra) to } \\
\text { smooth his sustenance, can't be harm } \\
\text { by sharp weapons, ward off magic, } \\
\text { saved from the enemy, can disappear, } \\
\text { loved by the public and others. }\end{array}$ & 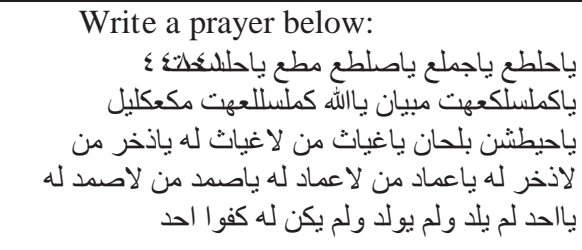 \\
\hline 21. & The pesantren has many students. & $\begin{array}{l}\text { After Maghrib prayer, they read } \\
\text { A smaul Husna. }\end{array}$ \\
\hline
\end{tabular}

\section{A nalysis of The Content Sufism}

Sufism madzhab, based on its tendencies and characteristics, can be divided into three madzhabs, namely Sufism fal safi, Salafi Sufism, and Sunni Sufism (akhlaqi/amali) although different opinions and manifestations, in general, Sufism practitioners can be said to agree that the teachings of Sufism are tazkiyyah al-Nafs (purification of self, both purification of body, speech, thought, heart, and soul; and the use of A llah A Imighty.), through takhalliy, tahalliy, and tajalliy to achieve closeness or union with God A Imighty (M ashar, 2015: 94).

The analysis of Sufism shows the efforts of Sufis with various traditions that they adhere to have a conception of the way (tariqat) to God. This path begins with spiritual exercises (riyadhah), then gradually goes through various phases, known as maqam (level) and things (circumstances), and ends with knowing (ma'rifat) to God. The story of recognition (ma'rifat) became a common goal pursued by Sufis. Sufi attitudes and behavior framew orks are manifested through specific practices and tariqat methods (A t-Taftazani, 1985: 35).

The journey to Allah is a method of understanding (ma'rifat) in a sense (spiritual) that is true to A Ilah SW T. M an will not know many of his Creators as long as he has not traveled to God, even though he is a believer in aqliyah because there is a significant difference between faith in aqliyah or logicaltheoretical (al-iman al-aqli an-Nazari) and faith in taste (al-iman asy-Syu'uri adz-dzauqi) (A nwar, 2010: 197).

Thelevel (maqam) is the level of a servant before him, in terms of worship 
Moh. Ashif Fuadi: Comparative Study of Manakib Nurul Burhani Book with Jawahirul Ma'ani and The Teachings of Sufism... (page 243-265)

and exercises (riyadhah) of the soul that he does. Among the Sufis, the order of maqam is different. Some of them formulate maqam-maqam simply, such as the series maqam qana'ah tawakal, tobat, inabah, wara', and zuhud. Meanwhile, al-Kalabadzi, in his book al-Ta'arruf li Madzhab al-Tashawuf makes repentance as the key to obedience, then zuhud, sabar, faqr, tawadhu', khauf, takwa, ikhlas, syukur, tawakal, rida, yakin, dhikr, uns, qarb, and mahabbah. Al-Qusyairi, in his book ar-Risalah al-Qusyairiyyah, gives the order maqamas follows, tobat, mujahadah, khalwat, 'uzlah, takwa, wara', zuhud, khauf, raja', qana'ah, tawakal, syukur, sabar, muraqabah, rida, ikhlas, dhikr, faqr, mahabbah, and syauq. The formulation of al-Ghazali is even less. He formulated maqam as follows, tobat, sabar, syukir, khauf, raja', tawakal, mahabbah, rida, ikhlas, muhasabah, and muraqabah (Anwar, 2010: 198).

Meanwhile, Ash-Syukhrawardi, in his book al-'Awarif al-Ma'arif formulated maqam to be, tobat, wara', zuhud, sabar, faqr, syukur, khauf, tawakal, and rida. In addition to the term maqam, there is also the term thing, namely the state or psychological condition when a Sufi reaches a certain maqam. According to al-Thusi, circumstances (things) do not include the effort of training-spiritual. Among the examples of things (circumstances) selfcentered (muraqabah), proximity or proximity (qarb), love (hubb), fear (khauf), hope (raja'), longing (syauq), intimate (uns), peaceful (thuma'ninah), witnessing (musyahadah), and sure (Ahmad, 1985: 102). From the description above, it is concluded that Abdul Qadir al-Jailani's thoughts on the concept of Sufism are more emphasis on improving individual human behavior. Through several stages of the primacy of purification of the soul: tobat, zuhud, tawakal, sabar, shidik, syukur, and Ridha will train the human soul (tazkiyyatuan-Nafs) to have a noble moral. Internalization of these values of purification of the soul will give rise to a person of good character (Mustaghfiroh et al., 2021: 35).

The comparison in Nurul Burhani and Jawahirul Ma'ani has many similarities in the hagiographic plot of Sheikh Abdul Qadir al-Jailani. As a man of knowledge, each author presents a different style of writing in which the Nurul Burhani is equipped with Javanese translation and is given the journal with journal's Jawairul Ma'ani Kyai Jauhari, while in the report of the book is more concise hagiographic content. Each part has more successive, soulinspiring of Sufism, exemplary value like takziyyatu al-Nafs, zuhud, tawakal, sabar, mahabbah, khauf, dan the others. 


\section{E. Conclusion}

It can conclude that the teachings contained in the two books of hagiography by ulama of Nusantara have many similarities, especially in terms of mahabbah to Sheikh Abdul Qadir al-Jailani. Both of Kiai many fields of religious science from the author's side, including Sufism and order. In addition to building a pesantren (Islamic boarding school), he has an influential role and influence in the community thanks to his istikomah (sustainable). The hagiographic book is widely practiced because it is believed to contain many fadhilah (virtues) by its practitioners, as stated in the explanation in the book. There is little difference in displaying the biographical plot of al-Jailani in each section of each book, where the highest level of equality induces with al-Lujaini al-Dni. The teachings of Sufism contained in each part are patience, gratitude, tawakkal, qonaah, zuhud, raja', khouf, and others. The book of hagiography's thoughts on the concept of Sufism is more emphasis on improving individual human behavior. Through several stages of the importance of purification of the soul: tobat, zuhud, tawakal, patience, honesty, gratitude, and pleasure will train the human soul to have a noble moral. Internalization of these values of purification of the soul will give rise to a person of good character. Character improvement, feeling for the better, and this main is what is immersed in virtue ethics that directs the focus of his attention to being human.

\section{REFERENCES}

Ahmad, A. (1985). Diktat Ilmu Akhlak dan Ilmu Tasawuf. Fakultas Syari'ah IAIN Sunan Gunung Djati.

Anwar, R. (2010). Akhlak Tasawuf. Pustaka Setia.

At-Taftazani, A. A.-W. A.-G. (1985). Madkhal Ila At-Tasawwuf Al-Islam (A. R. 'Usmani \& S. dari Z. ke Zaman (eds.)). Pustaka.

Bruinessen, M. Van. (2015). Kitab Kuning, Pesantren dan Tarekat (cetakan II). Gading Publising.

Danandjaja, J. (1997). Folklor Indonesia: Ilmu Gosip, Dongeng, dan lainlain. PT. Pustaka Utama Grafiti,.

Fuadi, M. A., \& Ibrahim, R. (2020). Implementasi Tasawuf Syekh Abdul Qadir al-Jailani dalam Majelis Manakib Al Barokah Ponorogo. Al- 
Moh. Ashif Fuadi: Comparative Study of Manakib Nurul Burhani Book with Jawahirul Ma'ani and The Teachings of Sufism... (page 243-265)

Adabiya: Jurnal Kebudayaan Dan Keagamaan, Volume 15, No. 02, 215-228. https://doi.org/10.37680/adabiya.v15i02.576

Khaq, M. (2015). Studi Kritik Kualitas Hadis Dalam Kitab al Nurul al Burhani fi Tarjamati al Lujaini al Dani Juz II. Skripsi UIN Walisongo Semarang. Mansyur, M. (n.d.). Tindak Lampah Romo Yai Syekh Ahmad Jauhari Umar Pendiri Jam'iyyah Manakib Jawahirul Ma'ani.

Mashar, A. (2015). Tasawuf/ : Sejarah, Madzhab, dan Inti Ajarannya. AlA'raf/ : Jurnal Pemikiran Islam Dan Filsafat, Volume 12, No. 1, 97. https://doi.org/10.22515/ajpif.v12i1.1186

Masrur, M. (2014). Melacak Pemikiran Tarekat Kyai Muslih Mranggen (19121981 M) melalui Kitabnya/ : Yawaqit al-Asani Fi Manaqib al-Syeikh Abdul Qadir al-Jilani. At-Taqaddum, Vol. 6, No. 2, 265-315.

Muhsinin, M. (2012). Ilmu Hikmah dalam Pandangan Perguruan Tapak Sunan di Desa Sidorejo Karangawen Demak. IAIN Walisongo.

Muslih. (2001). al-Nuru al-Burhani fii Tarjamati al-Lujaini al-Dani (II). Toha Putra.

Mustaghfiroh, S., Nazar, T. H., \& Safe, B. (2021). Etika Keutamaan Dalam Akhlak Tasawuf Abdul Qadir Al-Jailani/ : Relevansinya dengan Pengembangan Karakter Manusia. Vol. 05, No. 1, 23-37. https://doi.org/ 10.33852/jurnalin.v5i1.241

Sholahuddin, M. (n.d.). Sejarah Romo Yai Syekh Ahmad Jauhari Umar alHajj Pendiri dan Pengasuh Pertama PP. Tegalrejo Tanggulangin Kejayan Pasuruan. YPP. Darussalam.

Umar, A. J. (n.d.). Jawahirul Ma'ani Fii Manakibi Syekh Abdul Qadir alJailani. Pondok Pesantren Darussalam.

Yahya, S. (2020). Tradisi Manaqib Syekh Abdul Qadir Al-Jailani di Mushalla Raudlatut Thalibin Kembaran Kebumen. IBDA \% : Jurnal Kajian Islam dan Budaya, Vol. 18, No. 1, 15-30. https://doi.org/10.24090/ibda.v18i1. 3505

Yusuf, A. F. (2020). Kiai Muslih Mranggen Sang Penggerak dan Panutan Sejati. Mimbar Media dan Futuhiyyah Press.

Zahro, F. (2020). Nilai-Nilai Pendidikan Sosial Keagamaan dalam Kitab Manaqib al Nurul al Burhani fi Tarjamati al Lujaini al Dhani Karya Kiai Muslih bin Abdurrahman. Skripsi IAIN Salatiga. 